\title{
Benchmarkmanipulatie: het causaal verband tussen een geschonden gedragsnorm uit de BMR en manipulatieschade
}

\author{
Mr. N.A. Campuzano*
}

\begin{abstract}
De Benchmark Verordening (BMR) dient als preventief regelgevend kader ter voorkoming van de manipulatie van benchmarks. In deze bijdrage staat de aansprakelijkheid wegens schending van een gedragsnorm uit de BMR centraal. Meer specifiek spitst deze bijdrage zich toe op het aantonen van causaal verband tussen de schending van een gedragsnorm uit de BMR en schade door benchmarkmanipulatie.
\end{abstract}

\section{Inleiding}

Financiële benchmarks kunnen worden gebruikt voor de prijsstelling van financiële instrumenten en overeenkomsten. ${ }^{1} \mathrm{Het}$ gebruik van benchmarks heeft vele voordelen. Zo verminderen zij transactiekosten met betrekking tot prijsonderzoek en zorgen zij voor meer contractflexibiliteit door mee te bewegen met marktontwikkelingen. Benchmarks worden daarom in toenemende mate gebruikt in financiële transacties en zijn in een breed scala aan overeenkomsten verwerkt. De toenemende afhankelijkheid van benchmarks heeft echter ook een keerzijde. Na de financiële crisis heeft een aantal manipulatieschandalen plaatsgevonden. Het schandaal dat veruit de meeste aandacht heeft gekregen, staat bekend als het 'Libor-schandaal'.

De London Interbank Offered Rate ('Libor') is een benchmark die wordt gebruikt als referentierente voor de prijsstelling van onder meer (hypothecaire) leningen en derivaten. ${ }^{2}$ Libor wordt vastgesteld door het gemiddelde tarief te nemen waartegen een handjevol grote (internationale) banken in Londen

Mr. N.A. Campuzano is als PhD-fellow verbonden aan de afdeling Financieel Recht van de Universiteit Leiden.

1. Bepaalde benchmarks kunnen ook worden gebruikt om de prestaties van een beleggingsfonds te meten. Denk aan aandelenindices zoals AEX, S\&P 500 en MSCI World. Deze benchmarks laat ik in dit artikel verder buiten beschouwing.

2. De discontinuiteit van Libor is gepland in 2022. De voorbereidingen voor de transitie van Libor naar zogenoemde Risk Free Rates (RFR) zijn nog volop in gang. Zie voor de consequenties hiervan voor gebruikers: C.U. Yilmaz, LIBOR gebruikers opgelet!, TF 2018, nr. 3, p. 122-127. bereid is om van elkaar te lenen binnen een bepaalde looptijd. ${ }^{3}$ Deze banken, ook wel contribuanten genoemd, geven hun (in)schattingen door an een centrale partij, genaamd de beheerder, die vervolgens Libor berekent en vaststelt. ${ }^{4}$ Bijvoorbeeld bij een hypothecaire lening bestaat de rente vaak uit de Libor van de gekozen looptijd plus een opslag. Is de 1-maands Libor 0,2 procent en de opslag 2,8 procent, dan betaalt de kredietnemer 3 procent rente over die maand. ${ }^{5}$ In 2012 is aan het licht gekomen dat Libor jarenlang is gemanipuleerd door bepaalde werknemers van contribuerende banken. Deze werknemers kwamen samen in chatgroepen om hun (in)schattingen op elkaar af te stemmen teneinde Libor hoger of lager te laten eindigen. Omdat deze banken tevens grootschalige Libor-gebruikers waren, hebben zij jarenlang kunnen profiteren van het door bepaalde medewerkers opgezette manipulatieschema. ${ }^{6}$

$\mathrm{Na}$ het Libor-schandaal openbaarde zich dat meerdere benchmarks, gerelateerd aan andere rentevoeten, zoals de Euro Interbank Offered Rate ('Euribor'), commodities en valutakoer-

3. Libor heeft verschillende looptijden en kan variëren van: overnight (een dag), een week, een maand, twee maanden, drie maanden, zes maanden en twaalf maanden. Afhankelijk van de looptijd wordt Libor opnieuw vastgesteld. De 1-maands Libor wordt bijvoorbeeld elke maand opnieuw berekend en vastgesteld.

4. Sinds 1 februari 2014 is ICE Benchmark Administration de beheerder van Libor. Vóór 1 februari 2014 was dit de Britisch Banking Association (BBA).

5. Ten behoeve van het voorbeeld is een positieve Libor gebruikt. In mei 2019 was de werkelijke stand van de 1-maands Euro Libor - 0,42 procent.

6. Aan het eind van 2016 zijn rond een dozijn banken beboet voor bijna 10 miljard USD voor hun werknemers die verantwoordelijk waren voor (een bijdrage aan) de manipulatie van Libor. De geschatte totale schade van het Libor-schandaal is vele malen groter. Zie Yilmaz 2018, p. 122 en L. Vaughan, 'Broken Benchmarks', Bloomberg 2017. 
sen, de dupe zijn geworden van manipulatie. ${ }^{7}$ Volgens de Europese wetgever hebben deze schandalen aangetoond dat de manipulatie van benchmarks ernstige gevolgen heeft voor het vertrouwen in de markt en kan leiden tot aanzienlijke schade voor beleggers en consumenten. ${ }^{8} \mathrm{Om}$ die reden heeft hij allereerst een verbod op benchmarkmanipulatie opgenomen in artikel 15 jo. artikel 12 lid 1 sub d van de Verordening Marktmisbruik 9 (MAR). ${ }^{10}$ Het verbieden van benchmarkmanipulatie is op zichzelf echter onvoldoende om het vertrouwen in benchmarks te waarborgen. Benchmarks zijn namelijk inherent vatbaar voor manipulatie. ${ }^{11}$ Als aanvullende maatregel heeft de Europese wetgever daarom een preventief regelgevend kader opgesteld ter voorkoming van benchmarkmanipulatie in de vorm van de Benchmark Verordening ${ }^{12}$ (BMR). ${ }^{13}$

De BMR legt direct verplichtingen inzake governance en controle op aan personen die zijn betrokken bij het aanbieden van benchmarks ('beheerders'), het aanleveren van gegevens voor de berekening van benchmarks ('contribuanten') en gebruikmaken van benchmarks ('gebruikers'). ${ }^{14}$ Veruit de meeste van de verplichtingen uit de BMR zien echter op beheerders, die het best in staat zouden zijn om de risicofactoren van benchmarks zo veel mogelijk te voorkomen. Een van de redenen waarom de manipulatie van Libor zo lang heeft kunnen voortduren, is bijvoorbeeld dat de beheerder destijds blootstond aan een belangenconflict en daardoor niet tijdig ingreep. $^{15}$

7. Zie: R.M. Abrantes-Metz \& D.S. Evans, Enhancing Financial Benchmarks: Comments on the OICU-IOSCO Consultation Report on Financial Benchmarks, Competition Policy International 2013, p. 1-12; en Financial Conduct Authority, Barclays fined $£ 26 \mathrm{~m}$ for failings surrounding the London Gold Fixing and former Barclays trader Banned and fined for inaproppriate conduct, 2015.

8. Zoals in deze bijdrage wordt betoogd is het aantonen van schade door beleggers en consumenten geen geringe opgave.

9. Verordening (EU) nr. 596/2014 van het Europees parlement en de raad van 16 april 2014 betreffende marktmisbruik (Verordening marktmisbruik) en houdende intrekking van Richtlijn 2003/6/EG van het Europees Parlement en de Raad en Richtlijnen 2003/124, 2003/125/EG en 2004/72/EG van de Commissie, PbEU 2014, L 173 (Verordening Marktmisbruik).

10. Overweging 44 MAR. In Nederland vond de wetgever het van essentieel belang dat de manipulatie van benchmarks vóór de invoering van de MAR al werd verboden. Om die reden is art. 5:58a Wet op het financieel toezicht (Wft) per 1 januari 2015 in het leven geroepen.

11. Zie bijvoorbeeld: IOSCO, Principles for Financial Benchmarks, 2013, p. 3 en Rapport van de AFM en DNB, Langs de financiële meetlat. Nederlandse betrokkenheid bij financiële benchmarks, 2015, p. 10.

12. Verordening (EU) 2016/1011 van het Europees Parlement en de Raad van 8 juni 2016 betreffende indices die worden gebruikt als benchmarks voor financiële instrumenten en financiële overeenkomsten of om de prestatie van beleggingsfondsen te meten en tot wijziging van Richtlijnen 2008/48/EG en 2014/17/EU en Verordening (EU) nr. 596/2014, PbEU 2016, L 171 (Benchmark Verordening).

13. Overweging 1 en 8 BMR.

14. De definitie van een beheerder en een contribuant is te vinden in respectievelijk art. 3 lid 1 sub 6 BMR en art. 3 lid 1 sub 9 BMR. Wat valt onder het gebruikmaken van een benchmark is neergelegd in art. 3 lid 1 sub 7 BMR.

15. Zie bijvoorbeeld: G. Finch \& L. Vaughn, BBA Was Told Banks Lied About Libor to Boost Profits in 2007, Bloomberg Bus 2015.
In beginsel worden de publiekrechtelijke gedragsregels uit de BMR gehandhaafd door de bevoegde autoriteiten van de lidstaten. In Nederland is dat de Autoriteit Financiële Markten (AFM). Indien een benchmark is gemanipuleerd zullen gedupeerden - los van bestuursrechtelijke handhaving - hun schade willen verhalen. ${ }^{16}$ De aansprakelijkheidsprocedure vindt plaats volgens het nationaal privaatrecht. Toch is het mogelijk dat de schending van een publiekrechtelijke gedragsregel in bepaalde gevallen doorwerkt in het nationaal privaatrecht. In Nederland kan dit langs de band van de onrechtmatige daad (art. 6:162 Burgerlijk Wetboek (BW)). Een voorwaarde voor een succesvol beroep op artikel 6:162 BW is een causaal verband tussen de normschending en manipulatieschade aantonen. ${ }^{17}$

Het aantonen van causaal verband tussen een geschonden gedragsnorm uit de BMR en schade door benchmarkmanipulatie is echter geen geringe opgave. De schending van een gedragsnorm uit de BMR kan een benchmark vatbaar maken voor manipulatie, maar leidt niet direct tot een gemanipuleerde benchmarkwaarde en schade. In zulke gevallen kan het causaal verband het best in twee stappen worden aangetoond. De eerste stap, die voorwaardelijk is aan de tweede stap, is dat de schending heeft geleid tot een voor manipulatie vatbare benchmark. Alleen wanneer de schending heeft geleid tot een voor manipulatie vatbare benchmark, is de kans op manipulatie vergroot en kan worden gezegd dat de schending heeft bijgedragen aan manipulatie. De tweede stap is dat de door de schending ontstane vatbaarheid heeft geleid tot (manipulatie)schade. Het vergroten van de kans op manipulatie maakt niet meteen dat de benchmark is 'gemanipuleerd'. Hiervoor is nog vereist dat op de vatbaarheid is ingespeeld door een manipulatieve handeling.

In deze bijdrage staat de aansprakelijkheid van een beheerder wegens schending van de BMR centraal. ${ }^{18}$ Onderzocht wordt of een beheerder op grond van artikel 6:162 BW aansprakelijk kan worden gesteld voor manipulatieschade als deze een preventieve verplichting ter voorkoming van manipulatie uit de

16. Afhankelijk van de aard van het financiële instrument of de financiële overeenkomst dat aan de desbetreffende benchmark is verbonden, zal ofwel een hogere stand ofwel een lagere stand tot schade leiden. Deze schade bestaat uit het verschil tussen de prijs die voor het financieel instrument of de financiële overeenkomst is betaald en de prijs die zou zijn betaald voor het financieel instrument of de financiële overeenkomst als de benchmark niet was gemanipuleerd. Zie: C.C. van Dam, Civielrechtelijke aspecten van Libor en Euribor manipulaties, OR 2014 (9), par. 2.1.

17. Het causaal verband bestaat uit het condicio-sine-qua-nonverband en het toerekeningsverband ex art. 6:98 BW. In deze bijdrage zal ik mij zo veel mogelijk beperken tot het condicio-sine-qua-nonverband (hierna: 'causaal verband')

18. De auteur is zich ervan bewust dat er meerdere mogelijkheden zijn om manipulatieschade te verhalen, maar heeft opzettelijk voor deze benadering gekozen om twee redenen. Ten eerste om de toegevoegde waarde van de BMR voor gedupeerden van manipulatieschade te onderzoeken. Ten tweede om de consequenties voor het niet-naleven van de beheerder duidelijk in kaart te brengen. 
BMR schendt. ${ }^{19}$ Meer specifiek spitst deze bijdrage zich toe op het causaal verband tussen de schending van een gedragsnorm uit de BMR door een beheerder en schade door benchmarkmanipulatie. Omdat de Europese rechter noch de Nederlandse rechter zich heeft uitgelaten over deze kwestie, of het civiel effect van de BMR in het algemeen, zal ik uitgaan van een hypothetische situatie naar huidig Europees en Nederlands recht. ${ }^{20}$

De opzet van de bijdrage is als volgt. In paragraaf 2 behandel ik de eerste stap van het aantonen van causaal verband. Hiervoor gebruik ik het theoretische kader met betrekking tot benchmarkmanipulatie. Dat wil zeggen: aan de hand van de risicofactoren zal ik proberen vast te stellen welke schending bijdraagt aan een voor manipulatie vatbare benchmark. In paragraaf 3 bespreek ik de tweede stap van het causaal verband. Deze stap is - zo zal blijken - zeer complex en bevat meerdere causaliteitsproblemen. Ik zal onderzoeken in hoeverre de nationale civiele rechter naar Europees en Nederlands recht gedupeerden van benchmarkmanipulatie tegemoet moet en mag komen in die causaliteitsproblemen. In paragraaf 4 sluit ik af met een conclusie.

\section{Eerste stap: de schending heeft geleid tot een voor manipulatie vatbare benchmark}

De eerste stap in het aantonen van causaal verband tussen een geschonden gedragsnorm uit de BMR en manipulatieschade is dat de schending door een beheerder heeft geleid tot een voor manipulatie vatbare benchmark. Om te begrijpen welke gedraging kan leiden tot een vatbare benchmark, is kennis over de verschillende vatbaarheden noodzakelijk. Pas als duidelijk is wat de vatbaarheden zijn, kan wat worden gezegd over welke normschending bijdraagt aan een voor manipulatie vatbare benchmark. Hierna zal ik eerst de verschillende vatbaarheden uiteenzetten. Vervolgens zal ik op basis van die vatbaarheden uitzoeken welke bepalingen zijn gericht op de preventie daarvan en kwalificeren als 'kernbepaling'.

\subsection{De inherente vatbaarheden van benchmarks voor manipulatie}

Uit artikel 12 lid 1 sub d MAR volgt dat benchmarkmanipulatie bestaat uit: (1) het verspreiden van onjuiste of misleidende informatie met betrekking tot een benchmark, (2) het verspreiden van onjuiste of misleidende inputs met betrekking tot een benchmark of (3) enigerlei andere gedraging waardoor de berekening van een benchmark wordt gemanipuleerd. ${ }^{21}$

19. De meerderheid van de zaken als gevolg van de Libor- en Euribor-schandalen is gebaseerd op vernietigingsacties op grond van dwaling jegens banken waarmee een financieel instrument of een financieel contract is afgesloten. In deze casus ligt een vordering op grond van dwaling minder voor de hand, omdat gedupeerden van benchmarkmanipulatie zelden een contractuele relatie hebben met de beheerder.

20. In de praktijk hebben dergelijke situaties een internationale aard, waardoor eerst de bevoegdheid van de rechter en het toepasselijk recht moeten worden vastgesteld. In deze bijdrage ga ik uit van de bevoegdheid van de Nederlandse rechter en dat het toepasselijk recht Nederlands is.

21. Art. 15 jo. art. 12 lid 1 sub d MAR.
Het gemak waarmee een manipulator dergelijke manipulatieve handelingen kan verrichten en schade kan aanrichten, hangt af van de vatbaarheid van de betreffende benchmark voor manipulatie. Hoewel de omvang van de risico's varieert, hebben alle benchmarks bepaalde risicofactoren gemeen. ${ }^{22}$

De eerste risicofactor is belangenconflict. Als gezegd zijn er doorgaans drie categorieën partijen betrokken bij benchmarks, namelijk: beheerders, contribuanten en gebruikers. ${ }^{23}$ Een beheerder is de centrale partij die verantwoordelijk is voor het samenstellen en publiceren van een benchmark. Een contribuant is iedere partij die input levert aan een beheerder. Input wordt gebruikt voor de benchmarkberekening en is te onderscheiden in inputgegevens en transactiegegevens. Inputgegevens bestaan uit (in)schattingen, waarden of prijzen. ${ }^{24}$ Transactiegegevens bestaan uit transactiedata. ${ }^{25}$ Een gebruiker is simpelweg iedere partij die, op welke manier dan ook, gebruikmakkt van een benchmark. Deze partijen hebben verschillende en uiteenlopende belangen. Inherent aan benchmarks is de mogelijkheid om als partij meerdere rollen te vervullen. ${ }^{26}$ Dit leidt al gauw tot een belangenconflict wat een reden kan zijn voor manipulatie. ${ }^{27}$ Denk aan het Libor-schandaal. Hier waren de contribuerende banken tevens grootschalige gebruikers, wat zorgde voor een prikkel voor de werknemers om de standen te manipuleren. Daarnaast was de beheerder ten tijde van de manipulatie, de BBA, in feite een lobbyorganisatie voor de contribuerende banken, waardoor deze werd geprikkeld om minder streng op te treden tegen de banken. ${ }^{28}$

De tweede risicofactor is keuzevrijheid. De keuzevrijheid ziet op twee aspecten: de keuzevrijheid van contribuanten en de keuzevrijheid van beheerders. ${ }^{29}$ De keuzevrijheid van contribuanten ligt in het feit dat (bijna alle) benchmarks tot stand komen door vrijwillig geleverde input en ziet op de keuze om wel of niet (juiste en leidende) input te leveren aan de beheerder voor de benchmarkberekening. ${ }^{30}$ Deze keuzevrijheid kwam bijvoorbeeld tot uiting in het Libor-schandaal, waarbij contribuanten in eerste instantie de keuze hadden om de ene dag wel input door te geven en de andere dag niet. ${ }^{31}$ Daarnaast

22. Overweging $8 \mathrm{BMR}$.

23. Zie voetnoot 14 .

24. Art. 3 lid 1 sub 14 BMR.

25. Art. 3 lid 1 sub 15 BMR.

26. Rapport van de AFM en DNB februari 2015, p. 9; Rapport van de AFM en DNB, oktober 2015 p. 6 en ESMA en EBA Principles for BenchmarkSetting 2013, p. 4-5.

27. Overweging $12 \mathrm{BMR}$.

28. Zie: Wheatley Review, The Wheatley Review of LIBOR: final report, 2012, p. 21.

29. Overweging 8 en 12 BMR.

30. De keuzevrijheid van contribuanten komt voor bij beide vormen van input, te weten: inputgegevens en transactiegegevens. Bij inputgegevens is er keuzevrijheid om wel of geen gegevens te rapporteren en bij transactiegegevens is er keuzevrijheid om transacties buiten de benchmarkberekening aan te gaan. In beide gevallen hebben contribuanten de mogelijkheid om strategische beslissingen te nemen over het al dan niet leveren van input. Desalniettemin worden inputgegevens vaak beschouwd als gevoeliger voor manipulatie dan transactiegegevens. Zie: overweging $26 \mathrm{BMR}$.

31. Inmiddels kunnen de contribuanten van bepaalde benchmarks wel worden verplicht om input te leveren. Art. 23 BMR 
was het mogelijk voor de banken om onjuiste/misleidende schattingen door te geven, omdat (in)schattingen een bepaalde vrijheid met zich brengen. ${ }^{32}$

De keuzevrijheid van beheerders komt tot uiting in de invloed die zij kunnen uitoefenen op de benchmarkwaarde. Zo beschikken zij over keuzevrijheid bij het opstellen van de formule, de uitvoering van de berekening en de bepaling van de inputgegevens. ${ }^{33}$ In deze vrijheid liggen twee risico's. Het eerste risico is manipulatie door de beheerder. Denk aan een beheerder die ergens in het vaststellingsproces de bevoegdheid heeft om input te selecteren om mee te nemen in de berekening. Deze beheerder heeft een bepaalde keuzevrijheid die het mogelijk maakt om de benchmark te manipuleren. Het tweede risico is een voor manipulatie gevoelige benchmark. Door bijvoorbeeld te kiezen voor een bepaalde (zwakke) methodologie kan een beheerder de benchmark vatbaar maken voor manipulatie. Die gevoeligheid komt voornamelijk tot uitdrukking in de derde risicofactor.

De derde risicofactor is concentratie. ${ }^{34}$ Benchmarks geven een samenvatting van de desbetreffende markt op basis van een (klein) gedeelte van informatie over die relevante markt. Net als bij steekproeven, waarbij het makkelijker is om de metingen van de steekproef te vervalsen dan van de totale populatie, is het makkelijker om het gedeelte marktinformatie dat de benchmark reflecteert te manipuleren dan de gehele markt. Een manipulatieve handeling krijgt dus meer gewicht naarmate de concentratie van marktinformatie toeneemt. Met name ten aanzien van de volgende drie aspecten kan concentratie optreden: het benchmarkdomein, de contribuanten en de liquiditeit. ${ }^{35}$

De concentratie van het benchmarkdomein wordt bepaald door de hoeveelheid en soort marktinformatie die wordt meegenomen in de benchmarkberekening. Het stellen van eisen aan de marktinformatie, zoals: de hoeveelheid (bijvoorbeeld $10 \%$ van alle transacties), het tijdsvenster (bijvoorbeeld alleen transacties tussen 16.00 en 17.00 uur) en de geografische kwalificatie (bijvoorbeeld alleen transacties uit bepaalde WestEuropese landen), bepaalt in grote mate de concentratie van de benchmark. De impact van input is groter in een beperkt benchmarkdomein. De concentratie van het aantal contribuanten hangt af van de samenstelling van contribuanten die input leveren. Als slechts een klein en select groepje contribu-

32. De keuze om onjuiste of misleidende input door te geven zal al snel als onrechtmatig worden aangemerkt, maar voor de keuze om wel of geen juiste input door te geven is het nog maar de vraag of dat als onrechtmatig kan worden bestempeld.

33. Overweging 17 BMR.

34. De vatbaarheid concentratie is niet nadrukkelijk genoemd in de BMR maar volgt indirect uit de keuzevrijheid. Verstein beschouwt de concentratie wel als een vatbaarheid op zichzelf. Zie: A. Verstein, Benchmark Manipulation, Boston College Law Review 2015 (56), p. 230-231. Mijns inziens is dit een waardevol onderscheid, al is de term 'overconcentratie' hier misschien beter op zijn plaats.

35. Verstein heeft het over 'domain concentration', 'participants concentration' and 'liquidity concentration'. Zie: Verstein 2015, p. 230-231. anten input levert, is de concentratie veel sterker. Een enkele contribuant heeft meer impact op de benchmark als hij onderdeel uitmaakt van een kleine groep dan van een grote groep. De concentratie van liquiditeit is afhankelijk van de hoeveelheid en het gemak waarmee kan worden gehandeld binnen het benchmarkdomein. Een illiquide markt ziet al weinig handelsbeweging maar een benchmark in die markt ziet doorgaans nog minder. ${ }^{36}$ Daarnaast is het mogelijk dat een benchmark zich richt op minder liquide segmenten van een bepaalde markt. De impact van input is dus groter in illiquide markten.

\subsection{De kernbepalingen van de BMR}

$\mathrm{Nu}$ het begrip benchmarkmanipulatie en de inherente risicofactoren van benchmarks voor manipulatie zijn besproken, kan worden bepaald welke bepalingen uit de BMR specifiek zien op het voorkomen van benchmarkmanipulatie, en als 'kernbepaling' kunnen worden aangemerkt. De BMR legt naast beheerders een aantal van de verplichtingen die zien op het voorkomen van benchmarkmanipulatie op aan contribuanten en zogenoemde 'onder toezicht staande contribuanten' ${ }^{37}$ Dit zijn entiteiten die onder (financieel) toezicht staan, zoals banken, beleggingsondernemingen en verzekeraars. ${ }^{38}$ In deze bijdrage ga ik uitsluitend in op de verplichtingen voor een beheerder, omdat de aansprakelijkheid van een beheerder centraal staat. Hierna benoem ik per risicofactor welke bepalingen zijn gericht op het voorkomen daarvan.

\section{Bepaling(en) ter voorkoming van belangenconflicten}

De BMR besteedt in de preambule veel aandacht aan belangenconflicten. ${ }^{39}$ Concrete verplichtingen voor beheerders om passende governanceregelingen te treffen ter voorkoming of beheersing van belangenconflicten zijn neergelegd in artikel 4 BMR. Lid 2 van dat artikel verplicht om de werkzaamheden gerelateerd aan het aanbieden van een benchmark operationeel te scheiden van andere werkzaamheden. Lid 6 verplicht om passend beleid en passende procedures toe te passen (en te actualiseren), in het bijzonder om belangenconflicten te beperken als gevolg van de eigendom of controle van de beheerder, andere belangen in de groep van de beheerder of andere personen die invloed kunnen uitoefenen op de beheerder (sub b). Lid 7 verplicht om een aantal concrete eisen te stellen aan werknemers en andere natuurlijke personen die direct betrokken zijn bij het aanbieden van benchmarks. Tot slot verplicht lid 8 om specifieke interne controleprocedures op te stellen. Het verdient hier opmerking dat veel van de ver-

36. Benchmarks meten over het algemeen een (klein) gedeelte van de handel of informatie in de desbetreffende markt.

37. Kernbepalingen voor (onder toezicht staande) contribuanten zijn: art. 16 lid 1 sub a, 16 lid 1 sub c, 15 en 16 BMR

38. Art. 3 lid 1 sub 10 jo. 3 lid 1 sub 17 BMR.

39. Zie de overwegingen $1,8,12,21,31$ en 47 BMR. 
plichtingen die gelden voor beheerders niet van toepassing zijn op zogenoemde 'niet-significante benchmarks'. ${ }^{40}$

\section{Bepaling(en) ter voorkoming van keuzevrijheid}

De BMR veronderstelt dat bij het aanleveren van inputgegevens meer keuzevrijheid aanwezig is dan bij transactiegegevens en legt uit hoofde van die veronderstelling verplichtingen op aan beheerders. ${ }^{41}$ Artikel 11 lid 1 BMR verplicht beheerders om transactiegegevens te gebruiken indien deze beschikbaar en passend zijn om op nauwkeurige en betrouwbare wijze de markt of economische realiteit van de benchmark weer te geven. Daarnaast geldt voor beheerders ook de verplichting om de keuzevrijheid op een onafhankelijke en eerlijke wijze uit te oefenen op basis artikel 4 lid 1 BMR. Verder dienen beheerders in hun methodologie duidelijk aan te geven hoe en wanneer de keuzevrijheid kan worden uitgeoefend en dienen zij de uitoefening daarvan bij te houden in een register. ${ }^{42}$ Tot slot geldt de verplichting voor de beheerder om een benchmarkverklaring ex artikel $27 \mathrm{BMR}$ op te stellen. In de benchmarkverklaring moet, met betrekking tot de keuzevrijheid, ten minste zijn opgenomen wat de controles en voorschriften zijn om een consistente toepassing van de keuzevrijheid van beheerders en contribuanten te verzekeren. ${ }^{43}$

\section{Bepaling (en) ter voorkoming van concentratie}

De BMR gaat niet specifiek in op de risicofactor concentratie. Wel zijn beheerders ex artikel 11 lid 1 sub a BMR verantwoordelijk voor de eis dat de inputgegevens toereikend zijn om op nauwkeurige en betrouwbare wijze de economische realiteit weer te geven die de benchmark moet meten. Bovendien zijn beheerders bij het opstellen van de methodologie volgens artikel 12 lid 2 sub a BMR verplicht om rekening te houden met bepaalde (concentratie)factoren, zoals de omvang en de liquiditeit van de markt, marktconcentratie en de geschiktheid van steekproeven als afspiegeling van de markt of economische realiteit die de benchmark moet meten. Verder dient de beheerder het duidelijk te vermelden in de benchmarkverklaring als er een concentratie van input is. ${ }^{44}$

Indien één of meer van de hiervoor besproken kernbepalingen zijn geschonden, is dat reden voor de AFM om passende administratieve sancties op te leggen. ${ }^{45}$ Daarnaast zou het mijns inziens ook reden moeten zijn voor de civiele rechter om de eerste stap in het causaal verband tussen een geschonden gedragsnorm uit de BMR door een beheerder en manipulatieschade aan te nemen. De schending van een van de kernbepa-

40. Niet-significante benchmarks zijn benchmarks waarvan de totale gemiddelde waarde kleiner is dan $€ 50$ miljard. Art. 3 lid 1 sub 27 jo. art. 24 lid 1 BMR. De volgende verplichtingen van beheerders gelden niet voor niet-significante benchmarks: art. 26 jo. art. 4 lid 2, lid 7 sub c, d, e en lid 8 BMR. De volgende verplichtingen van contribuanten gelden niet voor niet-significante benchmarks: art. 26 jo. art. 16 lid 2 en lid 3 BMR.

41. Zie voetnoot 30 .

42. Art. 12 lid 1 sub b BMR en art. 8 lid 1 sub c BMR.

43. Art. 27 lid 1 sub b BMR jo. art. 27 lid 1 sub d BMR.

44. Art. 27 lid 2 sub g BMR.

45. Zie voor de passende administratieve sancties art. 42 lid 1 sub a BMR. lingen maakt een benchmark namelijk dusdanig vatbaar voor manipulatie dat wordt voldaan aan de eerste stap: de schending heeft geleid tot een voor manipulatie vatbare benchmark.

\section{Tweede stap: de vatbaarheid heeft geleid tot schade door benchmarkmanipulatie}

$\mathrm{Nu}$ duidelijk is hoe de eerste stap kan worden aangetoond en welke normschendingen leiden tot een voor manipulatie vatbare benchmark, kan worden overgegaan tot de tweede stap: de vatbaarheid heeft geleid tot schade door benchmarkmanipulatie. Deze stap is complexer en kan het best worden opgedeeld in twee onderdelen: (a) de vatbaarheid heeft geleid tot manipulatie; en (b) de manipulatie heeft geleid tot schade. Hierna zal blijken dat zich bij beide onderdelen verschillende causaliteitsproblemen voordoen. Conform de hoofdregel uit artikel $150 \mathrm{Rv}$ komt de bewijslast voor rekening van de partij die zich beroept op de rechtsgevolgen. In dit geval komen de causaliteitsproblemen dus voor rekening van de eiser die stelt dat er sprake is van een causaal verband. Onder uitzonderlijke omstandigheden, die worden gerechtvaardigd door een bijzonder regel of de eis van redelijkheid en billijkheid, kan de civiele rechter besluiten om de eiser tegemoet te komen in dergelijke causaliteitsproblemen. ${ }^{46}$ Voordat ik bespreek wat die causaliteitsproblemen zijn en welke mogelijkheden er zijn teneinde de eiser tegemoet te komen in het causaal verband, zal ik ingaan op de Europese beginselen van doorwerking in het nationaal (privaat)recht. Deze beginselen zeggen namelijk iets over de mate waarin de nationale civiele rechter rekening moet houden met de 'effectieve doorwerking' van de Europese normen bij civielrechtelijke procedures en bepalen voor een (groot) deel de vrijheid van de rechter om de eiser tegemoet te komen.

\subsection{Europese beginselen van doorwerking in het nationale (privaat)recht}

De BMR en de daarin vervatte (kern)bepalingen hebben hun oorsprong in het Europees recht. In hoeverre nationale civiele rechters mogen afwijken van die (kern)bepalingen hangt af van de door de Europese wetgever beoogde doorwerking. ${ }^{47} \mathrm{De}$ BMR bevat echter geen expliciete regeling ten aanzien van de eventuele doorwerking in nationaal privaatrecht. Volgens het Europeesrechtelijke beginsel van procedurele autonomie zijn lidstaten, bij gebreke aan een Europese regeling, vrij om zelf (civielrechtelijke) procedures in te richten met betrekking tot de handhaving van het Europese recht. ${ }^{48}$ Deze vrijheid voor

46. Dit geldt voor zowel het feitelijke causaal verband, zijnde het feitelijke oorzakelijke verband tussen een gebeurtenis en een bepaalde schadepost, als het bewijs van causaal verband, zijnde het bewijs van feiten die zich hebben voorgedaan die leiden tot de aansprakelijkheidsscheppende gebeurtenis. Zie: C.J.M. Klaassen \& J.S. Kortmann in hun preadviezen voor de VASR, Causaliteitsperikelen, Deventer: Kluwer 2012, p. 4 e.v.

47. Ik ga uitsluitend in op de BMR-kernbepalingen omdat deze specifiek zien op het voorkomen van manipulatie en de schade die daaruit voortvloeit. Bovendien zal voor deze bepalingen de doorwerking het sterkst zijn.

48. M. Haentjens, Incoherentie Verenigd. Privaatrechtelijke concepten onder druk van Europees financieel recht, TPR 2017, p. 18; en V.T. Tountopoulos, Market Abuse and Private Enforcement, ECFR 2014, p. 314-315. 
lidstaten wordt echter beperkt door de Europese beginselen van gelijkwaardigheid en effectiviteit. ${ }^{49}$ Het gelijkwaardigheidsbeginsel brengt met zich dat een nationale rechtsorde vorderingen gebaseerd op (schending van) Europese normen op gelijke voet dient te behandelen als vorderingen gebaseerd op het nationale (privaat)recht. Het effectiviteitsbeginsel brengt mee dat (vorderingen gebaseerd op) Europees recht volledig effect moeten verkrijgen en niet praktisch onmogelijk of uiterst moeilijk mogen worden gemaakt door (regelingen van) nationaal recht, zoals artikel 6:98 BW.50

In het veelbesproken World Online-arrest ${ }^{51}$ stond de Hoge Raad voor de vraag of de toepassing van artikel 6:98 BW de uitoefening van artikel 6 lid 2 Prospectusrichtlijn, ${ }^{52}$ dat in feite een concretisering van het effectiviteitsbeginsel is, praktisch onmogelijk of uiterst moeilijk maakt. De Hoge Raad beantwoordde die vraag bevestigend en overwoog kort weergegeven als volgt. ${ }^{53}$ Het bewijs van causaal verband tussen de misleiding en de beleggersbeslissing is problematisch, waardoor de in de Prospectusrichtlijn beoogde beleggersbescherming in de praktijk illusoir kan worden. ${ }^{54}$ Daarnaast legt artikel 6 lid 2 Prospectusrichtlijn de verplichting op aan lidstaten om het nationaal recht te voorzien van een effectieve rechtsbescherming. ${ }^{55}$ Met het oog op door de Prospectusrichtlijn beoogde beleggersbescherming en die effectieve rechtsbescherming, dient als uitgangspunt te worden genomen dat het causaal verband tussen de misleiding en de beleggersbeslissing aanwezig is. ${ }^{56}$

49. Zie voor meer factoren die de procedurele vrijheid kunnen beperken: Tountopoulos 2014, p. 315.

50. Zie HvJ EU 19 december 2013, C-174/12, ECLI:EU:C:2013:856 (Hirmann/Immofinanz), r.o. 40; HvJ EU19 juli 2012, C-591/10, ECLI:EU:C:2012:478, (Littlewoods), r.o. 27; HvJ EU 20 september 2001, C-453/99, ECLI:EU:C:2001:465 (Courage/Crehan), r.o. 29. Zie voor dit beginsel in de literatuur: Haentjens 2017, p. 19-20; M.W. Wallinga \& A.C.W. Pijls, De wisselwerking tussen Europees financieel toezichtrecht en nationaal privaatrecht. De indirecte invloed van de MiFID II op privaatrechtelijke aansprakelijkheid op het gebied van beleggingsdienstverlening en de onderbelichte invloed van de Richtlijn OHP, RMThemis 2018, afl. 1, p. 20-24; E. Vandendriessche, Investor Losses, (diss. Gent), Antwerpen: Intersentia 2014, p. 84 e.v.; D. Busch, Het civiel effect van de Marktmisbruikverordening, TF 2016, afl. 12, p. 528; en D. Busch, MiFID II/MiFIR: nieuwe regels voor beleggingsondernemingen en financiële markten, Preadvies voor de Vereniging voor Financieel Recht 2015, Deventer: Kluwer, p. 222-225;

51. HR 27 november 2009, ECLI:NL:HR:2009:BH2162, NJ 2014/201 m.nt. C.E. du Perron (Vereniging van Effectenbezitters c.s./World Online International NV).

52. De Prospectusrichtlijn is enkele jaren geleden gewijzigd als gevolg van Richtlijn 2010/73/EU.

53. Zie hierover uitgebreid: A.C.W. Pijls \& W.H. van Boom, Handhaving prospectusaansprakelijkheid niet illusoir: vermoeden van causaal verband bij prospectusaansprakelijkheid, WPNR 6834 (2010), p. 196-197; en B.J. de Jong, Liability for Misrepresentation - European Lessons on Causation from the Netherlands, ECFR 2011, p. 352-375.

54. Vereniging van Effectenbezitters c.s./World Online International NV, r.o. 4.11.1.

55. Vereniging van Effectenbezitters c.s./World Online International NV, r.o. 4.11.1.

56. Vereniging van Effectenbezitters c.s./World Online International NV, r.o. 4.11.2. Zie hierover uitgebreid: Pijls \& Van Boom 2010, p. 196-197 en De Jong 2011, p. 352-375.
Of hetzelfde uitgangspunt moet worden aangenomen in het geval dat een BMR-kernbepaling wordt geschonden, is niet uitgemaakt. ${ }^{57}$ In het kader van effectieve rechtsbescherming, zoals geformuleerd in World Online, is het aan de ene kant goed te verdedigen dat causaal verband moet worden aangenomen. De BMR beoogt namelijk een 'hoog niveau van consumenten- en beleggersbescherming te waarborgen'. ${ }^{58}$ Deze bescherming ziet onder meer op de schade die consumenten en beleggers kunnen leiden door benchmarkmanipulatie. ${ }^{59}$ Sterker nog, het is een van de doelstellingen van de BMR om voor (nationale) schadeclaims als gevolg van benchmarkmanipulatie een zo efficiënt en eerlijk mogelijke oplossing te bieden. ${ }^{60}$ In de literatuur wordt bepleit dat het causaal verband bij het overtreden van het verbod op marktmanipulatie (en dus benchmarkmanipulatie) uit de MAR als uitgangspunt moet worden genomen. ${ }^{61}$ Voor BMR-kernbepalingen zou hetzelfde kunnen worden gezegd, omdat deze in feite dezelfde onrechtmatige gedraging tegengaan, namelijk: benchmarkmanipulatie. Aan de andere kant is er ook het een en ander tegen in te brengen. Zo zwijgt de BMR over civielrechtelijke aansprakelijkheid. Bovendien heeft de AFM op basis van de BMR verschillende toezichts- en handhavingsmogelijkheden toegekend gekregen, waardoor de BMR een sterke toezichtsrechtelijke focus heeft. ${ }^{62}$

Totdat het Hof van Justitie van de Europese Unie zich erover uitlaat, is het onzeker of het Europeesrechtelijke effectiviteitsbeginsel zo ver strekt dat causaal verband tussen schending van een BMR-kernbepaling en schade door benchmarkmanipulatie moet worden aangenomen. In beginsel is het dus aan (het recht van) de lidstaten en de civiele rechter zelf om te beslissen of het causaal verband al dan niet wordt aangenomen.

\subsection{Onderdeel a: de vatbaarheid heeft geleid tot manipulatie}

Alvorens kan worden aangetoond of de vatbaarheid heeft geresulteerd in schade, dient eerst vast komen te staan dat de vatbaarheid heeft geleid tot manipulatie. Dat een benchmark vatbaar is voor manipulatie, wil nog niet zeggen dat deze ook daadwerkelijk is gemanipuleerd. Een beheerder overtreedt bijvoorbeeld een van de kernbepalingen, zoals het treffen van

57. In de literatuur is veel discussie over dit punt bij andere richtlijnen en verordeningen, zoals MiFID (II) en de MAR. Zie bijvoorbeeld: Busch 2016, p. 533-535; B.J. de Jong, Schade door misleiding op de effectenmarkt, (diss. RUN) (VHI-serie deel 103), Deventer: Kluwer 2010, p. 271-272; Asser/De Serière 2 - IV 2017/856; en Wallinga \& Pijls 2018, p. 20-24.

58. Zie: art. 1 en overweging $6 \mathrm{BMR}$.

59. Het gaat om schade als gevolg van tekortkomingen in of twijfels over de nauwkeurigheid en integriteit van benchmarks. Zie overweging 1 en 8 BMR.

60. Overweging $22 \mathrm{BMR}$.

61. Zie Busch 2016, p. 533-535; De Jong 2010, p. 271-272; en Asser/De Serière 2 - IV 2017/856. Zie anders met betrekking tot MiFID II: Wallinga \& Pijls 2018, p. 20-24.

62. Te denken valt aan de goedkeuring van vergunningen voor beheerders en de bevoegdheden waar deze toezichthouders over moeten beschikken. Zie titel 6 van de BMR. Volgens Wallinga en Pijls is dit een argument tegen het aannemen van causaal verband op grond van Europees recht. Zie Wallinga \& Pijls 2018, p. 21-22. 
passende governanceregelingen ter voorkoming of beheersing van belangenconflicten. ${ }^{63}$ Deze schending zorgt ervoor dat de betreffende benchmark vatbaar is voor belangenconflicten, maar makt nog niet dat de benchmark is gemanipuleerd. Voor dit laatste is nog vereist dat een manipulatieve handeling is verricht.

Het aantonen van stap 2(a) is daarom gebonden aan de voorwaarde dat een manipulatieve handeling is verricht. Van een manipulatieve handeling is in ieder geval sprake als een partij het verbod op benchmarkmanipulatie uit artikel 12 lid 1 sub d MAR heeft geschonden. ${ }^{64}$ Er zijn twee situaties denkbaar. In de eerste situatie schendt de beheerder een kernbepaling uit de BMR en verricht de beheerder zelf een manipulatieve handeling. In de tweede situatie schendt de beheerder een kernbepaling uit de BMR en verrichten één of meer derden een manipulatieve handeling. Denk aan het Libor-schandaal waarbij de beheerder blootstond aan een belangenconflict (wat nu hoogstwaarschijnlijk een schending van een van de kernbepalingen van de BMR had opgeleverd) en een groep derden (de werknemers van bepaalde contribuerende banken) die de manipulatieve handeling had verricht.

De eerste situatie laat ik verder buiten beschouwing, omdat alleen in de tweede situatie een moeilijkheid ontstaat met betrekking tot het aantonen van causaal verband. Die moeilijkheid zit voornamelijk in het feit dat het schadevoorval (de manipulatie) meerdere oorzaken kent die door verschillende partijen in het leven zijn geroepen, namelijk: schending van een BMR-kernbepaling door de beheerder en schending van het verbod op benchmarkmanipulatie uit de MAR door een derde. In zulke gevallen bestaat 'de manipulatie' dus uit twee delen: één is veroorzaakt door de schending van een BMRkernbepaling en de ander door de schending van het verbod op benchmarkmanipulatie uit de MAR. In dit kader zie ik voornamelijk twee leerstukken die oplossing zouden kunnen

63. Art. 4 BMR.

64. Een ruime interpretatie van het begrip manipuleren, een die zich niet beperkt tot de bewoordingen uit art. 12 lid 1 sub d MAR, sluit ik overigens niet uit. Het kan zijn dat de rechter in bepaalde gevallen voor een ruime interpretatie kiest, omdat het verbod niet is overtreden maar er wel sprake is van een onzuivere benchmarkwaarde. Zo bevat het verbod op benchmarkmanipulatie een subjectief bestanddeel, waardoor een gemanipuleerde benchmarkwaarde tot stand kan komen zonder dat het verbod is geschonden. bieden: meervoudige causaliteit en proportionele aansprakelijkheid. ${ }^{65}$

\section{Meervoudige causaliteit}

Het leerstuk van meervoudige causaliteit biedt een oplossing in situaties waarin de gewone wijze van beoordeling van causaliteit niet goed kan worden uitgevoerd. ${ }^{66}$ Het gaat dan om schade waarvoor diverse mogelijke oorzaken zijn aan te wijzen, zonder dat exact wordt bepaald of al deze oorzaken in causaal verband staan met de schade. Onder de noemer meervoudige causaliteit vallen meerdere, te onderscheiden soorten, zoals samenlopende oorzaken, afzonderlijke oorzaken, hypothetische causaliteit en alternatieve causaliteit. In deze situatie is voornamelijk de variant samenlopende oorzaken van belang, omdat deze ziet op gevallen waarin ieder van de afzonderlijke oorzaken noodzakelijk is voor het intreden van dezelfde schade. ${ }^{67}$ Zonder schending van een BMR-kernbepaling zou de manipulatieve handeling die inspeelt op de daardoor ontstane vatbaarheid niet mogelijk zijn en zonder manipulatieve handeling, zoals het schenden van het verbod op benchmarkmanipulatie uit de MAR, zou de benchmark niet (met hetzelfde gemak) zijn gemanipuleerd. ${ }^{68}$ Afzonderlijk zijn de schendingen ontoereikend om een beheerder aansprakelijk te stellen wegens schending van de BMR. ${ }^{69}$

Het antwoord op de vraag tot welke omvang iedere dader aansprakelijk is, kan worden gevonden in het arrest Nugteren/ Meskes. ${ }^{70}$ In dit arrest besliste de Hoge Raad kortgezegd dat indien twee of meer oorzaken noodzakelijke voorwaarden zijn voor het intreden van de schade, ieder van de aansprakelijke personen voor de gehele schade is aan te spreken. ${ }^{71}$ Dit volgt

65. Het leerstuk van groepsaansprakelijkheid ex art. 6:166 BW is ook wel eens geopperd als mogelijke oplossing om gedupeerden van benchmarkmanipulatie tegemoet te komen, met name in de context waarin de contribuanten als groep worden aangesproken voor hun manipulatieve handelingen. Tot nu toe is een beroep op art. 6:166 BW echter nog niet succesvol gebleken. Daarnaast is het maar de vraag of art. 6:166 BW ook kan worden toegepast in situaties waarin een beheerder de BMR overtreedt en een andere partij een manipulatieve handeling verricht. Om deze redenen laat ik dit leerstuk verder buiten beschouwing. Zie voor groepsaansprakelijkheid in het kader van benchmarkmanipulatie bijvoorbeeld: C.C. van Dam, Civielrechtelijke aspecten van Libor en Euribor manipulaties, OR 2014, afl. 9, par. 2.2 en Rb. Midden-Nederland 30 december 2015, ECLI:NL:RBMNE:2015:9174, JOR 2016/196 m.nt. J.W.P.M van der Velden.

66. T.F.E. Tjong Tjin Tai, Meervoudige causaliteit, WPNR 2018, afl. 7186, p. 237.

67. De overige vormen van meervoudige causaliteit gaan ervan uit dat alle oorzaken individueel verantwoordelijk kunnen zijn voor de gehele schade. Zie: T.F.E. Tjong Tjin Tai, Meervoudige causaliteit, bewijs en draagplicht. (HR 18 december 2009, LJN BK0873 London/Delta Loyd), BB 2010 , afl. 4 p. $98-99$.

68. Hoewel beide normschendingen niet met het uitgangspunt van volledige schade in causaal verband staan, voorkomt de toerekening naar redelijkheid uit art. 6:98 BW dat geen van de foutenmakers schadeplichtig is. Zie: Klaassen \& Kortmann 2012, p. 4.

69. Uiteraard is schending van het verbod op benchmarkmanipulatie uit de MAR wel voldoende om de derde aansprakelijk te stellen.

70. HR 24 december 1999, ECLI:NL:HR:AA4004, NJ 2000/351 (Nugteren/Meskes).

71. Zie Nugteren/Meskes, r.o. 3.7. 


\section{Maandblad \\ Ondernemingsrecht}

uit artikel 6:102 BW, dat de hoofdelijke aansprakelijkheid regelt. ${ }^{72}$ Dit betekent dat zowel de beheerder, die een BMRkernbepaling heeft geschonden, als de manipulator, die het verbod op benchmarkmanipulatie heeft geschonden, aansprakelijk is voor de gehele schade.

\section{Proportionele aansprakelijkheid}

Mocht de rechter minder zeker zijn over de noodzaak van beide overtredingen - één of meer BMR-kernbepaling(en) en het verbod op benchmarkmanipulatie - voor het intreden van de manipulatieschade, dan staat hem mogelijk een proportionele benadering ten dienste. Het leerstuk van de proportionele aansprakelijkheid kan in zulke situaties uitkomst bieden. De proportionele aansprakelijkheid biedt een oplossing in bepaalde situaties waarin causaliteitsonzekerheid bestaat tussen de geschonden norm en de schade en het onduidelijk is of het nadeel is veroorzaakt door de normschending van de aangesproken partij, dan wel door een omstandigheid die aan een ander dan de aangesproken partij is toe te schrijven of door een combinatie van beide, en de kans op de schadeveroorzaking niet zeer klein of zeer groot is. ${ }^{73}$ De schadevergoeding wordt dan berekend aan de hand van een in een percentage uitgedrukte kans dat de schade door haar normschending is veroorzaakt. Om proportionele aansprakelijkheid aan te nemen, moet de schade vaststaan. ${ }^{74}$ Dit kan eventueel een belemmering vormen voor gedupeerden van benchmarkmanipulatie, omdat de schadevaststelling uiterst complex kan zijn. $^{75}$

Desalniettemin denk ik dat de rechter het leerstuk van de proportionele aansprakelijkheid zou kunnen toepassen. De aansprakelijkheid van een beheerder die een BMR-kernbepaling schendt, staat immers vast en de kans dat die schending leidt tot manipulatieschade is niet zeer klein. Een vatbare benchmark staat namelijk bloot aan manipulatierisico. Bovendien rechtvaardigen de strekking en de aard van de BMRkernbepalingen een proportionele aanpak.

\subsection{Onderdeel b: de manipulatie heeft geleid tot schade}

Indien vaststaat dat de normschending heeft geleid tot manipulatie, moet stap 2(b) 'de manipulatie heeft geleid tot schade' worden aangetoond. Ten eerste zal moeten worden vastgesteld

72. Zie W.H. van Boom, Meervoudige oorzaken, hoofdelijke aansprakelijkheid en toerekening naar redelijkheid, in: A. Hammerstein e.a., Causaliteit, Den Haag: Vermande 2003, par. 1; en Tjong Tjin Tai 2018, p. 238. Zie anders: A.J. Akkermans, Oorzakelijk verband, in: M.E. Franke (red.), Onrechtmatige daad, BW Krant Jaarboek 12, Deventer: Kluwer 1996, p. 43.

73. Zie HR 31 maart 2006, ECLI:NL:HR: 2006:AU6092, NJ 2011/250 (Nefalit/Karamus), r.o. 3.13. Of de kans niet zeer klein of zeer groot is hangt af van: (1) de strekking van de geschonden norm, (2) de aard van de normschending en (3) de aard van de schade. Zie ook: HR 24 december 2010, ECLI:NL:HR:2010:BO1799, NJ 2011/251 (Fortis/Bourgonje).

74. HR 24 december 2010, ECLI:NL:HR:2010:BO1799, NJ 2011/251 (Fortis/Bourgonje).

75. Zie voor de complexiteit van de schadeberekening bij benchmarkmanipulatie: C.C. van Dam, Civielrechtelijke aspecten van Libor en Euribor manipulaties, OR 2014, afl. 9, p. 436-437. wat de benchmarkwaarde zou zijn geweest zonder de manipulatieve handeling. Hiervoor is inzicht nodig in de exacte formule aan de hand waarvan de benchmark wordt berekend. Hoewel de exacte methodologie vaak niet openbaar is, zal dat niet een al te groot probleem zijn. ${ }^{76}$ De benadeelde kan namelijk inzage vorderen op grond van artikel $843 \mathrm{a} \mathrm{Rv} .{ }^{77}$ Ook kan een rechter oplegging bevelen en, als partijen dit zonder gewichtige redenen weigeren, daaraan de gevolgen verbinden die hij geraden acht, waaronder een omkering van de bewijslast. ${ }^{78}$ Als gedupeerden de exacte methodologie eenmaal hebben achterhaald en het waardeverschil is berekend, dan is het alsnog de vraag of het waardeverschil is ontstaan door de manipulatie of andere factoren, zoals de marktwerking en het (handels)gedrag van contribuanten. Ook hier staan gedupeerden voor een buitengewoon moeilijke uitdaging.

Ten tweede moeten gedupeerden aantonen hoe het waardeverschil heeft geleid tot schade. $\mathrm{Zij}$ moeten aantonen hoe hun financieel instrument of financieel contract wordt beïnloed door het waardeverschil. Hierbij zijn van belang de aard van het instrument of contract en de kwetsbaarheid voor waardeveranderingen. In sommige gevallen zal een gedupeerde moeten aantonen dat hij een beleggingsbeslissing niet zou hebben genomen, bijvoorbeeld bij het te veel betalen voor een derivaat waarvan de waarde afhangt van een benchmark. In andere gevallen is geen sprake van een beleggingsbeslissing en is het voldoende als wordt aangetoond dat de waardeverandering nadelig is, bijvoorbeeld bij een te hoge maandelijkse hypotheekrenteaflossing die wordt bepaald door een benchmark.

Beide voorwaarden maken het aantonen van causaal verband tussen de manipulatieve handeling en schade bijzonder moeilijk. Het betreft hier met name een moeilijkheid in het bewijs van causaal verband.

\section{De omkeringsregel}

De omkeringsregel zou uitkomst kunnen bieden om het causaal verband tussen de manipulatie en de daadwerkelijk schade aan te tonen. Op grond van de omkeringsregel kan behoudens tegenbewijs (een vermoeden van) causaal verband tussen normschending en een verwezenlijkt gevaar door de rechter worden aangenomen. ${ }^{79}$ Hiervoor dient echter wel een 'nauwe band' te bestaan tussen de geschonden norm en het specifieke, gematerialiseerde risico. ${ }^{80} \mathrm{Om}$ die nauwe band vast te kunnen stellen, dient: (1) de geschonden norm te strekken tot

76. Hoewel de BMR meer transparantie heeft gecreëerd met betrekking tot gebruikte methodologieën, is een beheerder verplicht om alleen bepaalde elementen bekend te maken aan het publiek. Zie art. 13 en overweging 27 BMR.

77. De internationale setting van de benchmarkpraktijk maakt het wel lastiger om daadwerkelijk inzage te krijgen in de stukken.

78. Art. $22 \mathrm{Rv}$.

79. Anders dan de naam doet vermoeden, betreft het niet echt een omkering van de bewijslast.

80. J. den Hoed, Scheidslijn tussen kansschade, proportionele aansprakelijkheid en de omkeringsregel. Enkele praktische opmerkingen over verschillen tussen deze drie leerstukken naar aanleiding van HR 27 oktober 2017, ECLI:NL:HR:2017:2786, MvV 2018, afl. 6, p. 195. 
bescherming tegen de schade; (2) het specifieke gevaar waartegen de norm beoogt te beschermen te zijn verwezenlijkt; en (3) de norm specifiek bescherming te bieden aan het onmiddellijke gevaar. ${ }^{81}$

Ook is er een zogenoemde 'informele' variant van de omkeringsregel, ${ }^{82}$ die in feite neerkomt op de normatieve grondslag van de omkeringsregel: dat in gevallen waarin de geschonden norm dat rechtvaardigt een bewijsvermoeden kan worden aangenomen. ${ }^{83}$ Deze sterk aan de omkeringregel verwante benadering is bijvoorbeeld an bod gekomen in de effectenlease-arresten $^{84}$ en het reeds besproken World Online. ${ }^{85} \mathrm{Zo}$ is in dit laatste arrest beslist dat de normatieve grondslag van de omkeringsregel, te weten dat het redelijk kan zijn om uit te gaan van het causaal verband met betrekking tot de 'effectieve rechtsbescherming' van een bepaalde norm, ook kan worden toegepast buiten de 'formele' omkeringsregel. ${ }^{86}$ In World Online is (onder meer) een Europese grondslag gebruikt voor de toepassing van deze regel. Dit is echter niet nodig, daar de Nederlandse vermogensrechtelijke regels eenzelfde uitkomst kunnen bewerkstelligen. ${ }^{87}$

Mijns inziens zou de omkeringsregel kunnen worden toegepast. Er is in het onderhavige geval duidelijk sprake van een nauwe band. De BMR-kernbepalingen strekken namelijk tot bescherming tegen benchmarkmanipulatie en de schade die daaruit voortvloeit. Indien een van de BMR-kernbepalingen wordt geschonden en de benchmark is gemanipuleerd, dan heeft het specifieke gevaar - benchmarkmanipulatie - zich verwezenlijkt. Ook de informele variant leent zich wat mij betreft voor toepassing. Gelet op de doelstellingen van de BMR en de effectieve rechtsbescherming, zoals verwoord in World Online, zou het aannemen van causaal verband wenselijk zijn. ${ }^{88}$ Dus ongeacht welke variant wordt toegepast, of dat nou is op basis van een nauwe band tussen normschending en schade of op basis van de effectieve rechtsbescherming, in beide gevallen zou de uitkomst moeten zijn dat (het bewijs

81. Den Hoed 2018, p. 195.

82. Zie voor de term 'informele omkeringsregel': A.J.P. Schild, Het condicio sine qua non-verband bij de schending van een zorgvuldigheidsverplichting: enige wegen naar Rome, RMThemis 2009, p. 263.

83. Akkermans \& Van Dijk 2012, p. 168 en 176.

84. HR 5 juni 2009, ECLI:NL:HR:2009:BH2811, NJ 2012/183 (Levob/ Bolle) en HR 5 juni 2009, ECLI:NL:HR:2009:BH2822NJ 2012/182 (GeSP/Aegon).

85. Zie I. Giesen, Effectieve rechtsbescherming en causaliteit, AV\&S 2010, afl. 17, p. 127-128 en Schild 2009, p. 263.

86. Volgens Akkermans en Van Dijk is de normatieve grondslag van de omkeringsregel in World Online toegepast. Zie: Akkermans \& Van Dijk 2012, p. 168 en 176

87. Zie HR 27 november 2009, NJ 2014/201, m.nt. C.E. du Perron, par. 3. Een Nederlands effectiviteitsbeginsel bestaat overigens niet. Zie: T.F.E. Tjong Tjin Tai, Effectiviteitsbeginsel en nationaal privaatrecht, WPNR 2011, afl. 6901 p. 790-797.

88. Zie voor argumenten, zowel voor als tegen, voor het aannemen van het bewijs voor causaal verband op grond van effectieve rechtsbescherming par. 2.1. voor) causaal verband tussen manipulatie en schade door benchmarkmanipulatie kan worden aangenomen. ${ }^{89}$

\section{Conclusie}

De BMR is opgesteld met de manipulatieschandalen in het achterhoofd. Het is dan ook geen verrassing dat deze verordening is gericht op de preventie van manipulatie. Het ligt in de rede dat de schending van de preventieve gedragsnormen leidt tot aansprakelijkheid van de beheerder voor schade als gevolg van benchmarkmanipulatie. Toch is het vaststellen van aansprakelijkheid niet zo makkelijk als het op het eerste gezicht lijkt, omdat er verschillende moeilijkheden zijn in het aantonen van causaal verband. Welke moeilijkheden dit zijn, komt het best naar voren indien het causaal verband tussen een geschonden gedragsnorm uit de BMR en schade door benchmarkmanipulatie in twee stappen wordt gesplitst. De eerste stap is dat de normschending leidt tot een voor manipulatie vatbare benchmark. Om deze stap aan te tonen heb ik voorgesteld om gebruik te maken van het theoretische kader met betrekking tot benchmarkmanipulatie en de inherente risicofactoren van benchmarks daarvoor. Bepaalde gedragsnormen uit de BMR, die ik kernbepalingen heb genoemd, zijn dusdanig gericht op het voorkomen van manipulatie, dat schending daarvan een benchmark vatbaar maakt voor manipulatie. De tweede stap is dat de vatbaarheid leidt tot schade. Om deze stap aan te tonen zal de civiele rechter moeten beslissen om de causaliteitsonzekerheid weg te nemen. Ik heb voorgesteld om de informele omkeringsregel of een vergelijkbare benadering zoals in het World Online-arrest toe te passen. Ook lijken mij het leerstuk van meervoudige causaliteit en de proportionele aansprakelijkheid mogelijk oplossingen, met name in gevallen waarin één of meer derden een manipulatieve handeling verrichten.

Voor zover een beheerder een BMR-kernbepaling schendt en de rechter redenen ziet om gedupeerden tegemoet te komen in eventuele causaliteitsproblemen, is de BMR een toevoeging voor gedupeerden van benchmarkmanipulatie om hun schade te verhalen. In dergelijke gevallen kunnen zij, naast de manipulator, de beheerder aanspreken. Uit deze bijdrage mag echter duidelijk zijn geworden, voor zowel gedupeerden als beheerders, dat de aansprakelijkheid van benchmarkbeheerders voor manipulatieschade ook na de BMR nog steeds geen gegeven is.

89. De omkeringsregel en de informele variant kunnen mijns inziens worden toegepast op het causaal verband tussen normschending en schade voor zowel het gedeelte van manipulatie dat is ontstaan door een geschonden BMR-kernbepalingen als het gedeelte van manipulatie dat is ontstaan door schending van het verbod op benchmarkmanipulatie uit de MAR. 